\title{
The research of students' psychology climate at secondary schools
}

\author{
Y. Khomenko \\ PNPU named after VG Korolenko, Poltava, Ukraine \\ Corresponding author. E-mail: yevheniia1986@gmail.com
}

Paper received 20.10.19; Accepted for publication 08.11.19.

\section{https://doi.org/10.31174/SEND-PP2019-208VII85-14}

\begin{abstract}
The article presents the theoretical definition of the psychological climate of the student group. The psychological climate is considered as a dynamic entity, which includes both group processes and individual characteristics of students. A great attention is paid to the collective interaction that affects the climate. The empirical study of psychological climate in high school pupils' classes is thouroughly described, methods of mathematical statistics are used for reliability and the interpretation of the results. There are 461 students from the Poltava Gymnasium who study in $5-7^{\text {th }}$ grades. It was found that $27 \%$ of students estimate their psychological climate as high, $44 \%$ - as the average and 33\% - as low. Therefore, the psychological climate in the majority of the studied student groups - at medium and high levels, indicats the favorable conditions for the harmonious and comprehensive development of children.
\end{abstract}

Keywords: psychological climate, school climate, student group, adolescent age, interpersonal relations.

Introduction. The development of a harmonious person has a priority in the educational work of educational institutions. After all, development involves not only physical and physiological changes of the body, but also psychological ones, associated them with thinking, feelings, behavior, influence of society. The most controversial age is the teenage age that a child has to attend in a high school. It is at this time that the decisive influence of peer circles on the development of the personality of the adolescent, on his thoughts and behavior is observed. The environment directly affects the child at this time. Considering the fact that most of their time the students are in educational activities, and therefore in the student group, the mutual relationships in this group and the psychological climate of the collective as a whole are of great importance for their full and harmonious development. So, we face the problem of the psychological climate of the student group as a precondition for effective and complete versatile development of the individual.

Determination of the psychological climate. In psychological literature, there is still no general and conventional definition of a term psychological climate. In particular, there are concepts of "socio-psychological climate", "moral and psychological climate", "psychological mood", "psychological atmosphere", "socio-psychological situation", etc. The problem of socio-psychological climate in the team is devoted to many works in both national and foreign scientific literature. A considerable attention was paid to this study by G. M. Andreiev, V. M. Myasishchev, B. A. Parigin, K. K. Platonov.

So, according to B. Paryhin (1999), qualitative and quantitative indicators of the main features of the collective are combined with the concept of "socio-psychological climate of the collective" - which reflects the nature of the relationship among people, the prevailing tone of social mood in the team, associated with satisfaction of living conditions, style and level of governance and other factors.[1]

Among foreign researchers, one should mention Parker C.P., Baltes B.B., Young S.A., Huff J.W., Altmann R.A., Lacost H.A. \& Roberts J.E. (2003), who emphasized that there is a certain confusion in determining the "psychological climate" along with the terms "Collective climate", "organizational climate", and "organizational culture". They emphasize the measurement of this phenomenon by aggregating the psychological perception of the climate.[7, p.390]
H.Jerome Freiberg and T.A.Stein (1999) consider that the concept of "psychological climate" through the prism of "school climate" - as a quality school that helps each person to feel personal value, dignity and importance, while helping to create a sense of belonging to something beyond themselves. The school climate can contribute to sustainability or become a risk factor for people who work and study in a place which is called a "school". It is the school's climate that can determine the quality of a school that creates healthy learning. [5]

In our work, we proceed from the definition that the psychological climate of the student group is a complex multicomponent phenomenon, the analysis of which requires a comprehensive system approach, because it is necessary to take into account the specifics of the functioning of the group in the context of socio-cultural conditions, features of professional role functions and personality characteristics of its members. It is the psychological climate of the group that determines the psychological well-being of each student in the group and the dynamics of group processes. The essence of each person is revealed only in relations with other people and is realized in the forms of collective interaction, in the processes of communication. We believe that people are aware of their social value through relationships.

Based on the latest research by Hye-Kyoung Joea, Phil Hivera, Ali H. Al-Hoorie (2017), the study of social climate in the classroom involves three complementary designs, namely academic support for teachers, emotional support for teachers, and mutual respect in class. Accordingly, the emotional and psychological comfort of a student depends on emotional support, a sense of their significance, mutual respect with peers and a focus on learning. [6, p.138]

According to Sriklaub, K., Wongwanich, S., \& Wiratchai, N. (2015), classroom climate is the combination of feelings of teachers and students during a classroom is the result of teacher behavior (i.e., teaching methods, techniques) and student behavior (for example, continuous cooperation, participation in events, etc.)[8, p.1357]

In the opinion of Z. Pushkar, G. Voitovich (2013), the psychological climate is not a static but rather dynamic entity. At different stages of development of the collective there is a dynamics of the modality of emotional relations. At the first stage of the formation of the collective emotional factor plays a major role (there is an intensive process of psychological focus, establishing positive relationships). At the same stage, the formation of the collective becomes 
increasingly important cognitive (cognitive) processes, and each person acts not only as the object of the emotional communication, but also as an owner of certain personal qualities, social norms and attitudes. It is at this stage we can notice the formation of common views, values and norms.[2, p. 254]

Any person when they are in a social group, and moreover when taking part in common activities, affects the various spheres of life of the collective, including its sociopsychological climate. Accordingly, classroom students positively or negatively affect the well-being of others depending on their socio-psychological and individualpsychological properties. The socio-psychological properties of the person, who positively affects the formation of sociopsychological climate, include such features as responsibility, discipline, active interpersonal relationships, sociability, culture of behavior, tolerance. The negative impact on the climate is made by people who are arrogant, selfish, stagnant, etc. (another matter, as well as how the person understands himself). The balanced person himself has a great influence on the general climate in the team, it is influenced by the features of mental processes (intellectual, emotional, volitional), as well as the temperament and character of the members of the collective.

We can conclude that the psychological climate is a result of the joint activity of people, their interpersonal interaction. It manifests itself in such group effects as mood and collective opinion, an individual stability in the team.

Undoubtedly, the psychological climate in the school group affects both the personal development of each pupil and the group processes. In particular, a comfortable and safe environment for high school students becomes of great significance, since this period correlates with the age adolescence, which involves the importance of relationships with their peers and significant adults (teachers). Most of the time, students are in training, and therefore classmates and teachers influence their psychological state. (Sedykh K.V., 2008)

Features of adolescence. It should be noted that teenage age involves changes in the mental field of a personality. New conditions for the development of adolescents predetermine a new social situation in the development of adolescents. The school remains the main social environment of the child, but the motive of interaction with the social environment is changing. Without ignoring learning, the teenager begins to prefer communication. Thus, the main motive is communication with peers. Therefore, gradually the leading activity of this age is intimate-personal communication with peers. There are other new motives, which include the appearance of "sympathy" and "antipathy" in the study subjects. Also, there is affection, or disgust to his school; for the teenager become important results of control of his training - assessment.

Significant shifts occur in the formation of intellectual activity, intensive development acquire volitional features, actively formed self-awareness and self-esteem, there is an increased interest in the assessment of surrounding personal qualities, a teenager begins to develop their own worldview, attitude to society, people and themselves. It is at this time that the environment and the psychological climate of this environment are becoming extremely important. After all, in a comfortable psychological conditions, the development of a person goes more harmoniously.
Sedykh K.V. (2015) confirms that during communication with the peers, a teenager gets necessary knowledge about life that for one reason or another he can not get from adults. A group of peers produces adolescent social interaction skills. Only here, he can act as a guide and leader, commander and subordinate, a teacher and a student.[3,4]

The object of our study is the psychological climate of the group.

The subject of the study is the level of psychological climate of high school students' groups.

The purpose of our work is to investigate the psychological climate of high school students' groups, while comparing the results of 5th, 6th, and 7th grade students, as well as comparing the difference in estimation of boys and girls.

Research methods. To determine the level of psychological climate of student groups, we use an empirical method - a questionnaire, namely, "The methodology for researching the socio-psychological climate of a group" (Test "Socio-psychological climate in a group"). In order to compare the results and find differences, methods of mathematical statistics (Mann-Whitney's U-criterion) are used.

The research procedure suggests: the students were offered 13 polar judgments, which concerned their team, which reflected the properties of the psychological climate of their group. It was necessary to put an assessment that corresponds to the truth.

Here we suggest a scale for assessing the properties of the psychological climate:

3 - the property is manifested in the group always;

2 - the property is found in most cases;

1 - the property is often found;

0 - the same and the same properties appear to the same extent.

Processing results: after completing the research form, the summing up of the marks is separate from the left and right side of the form. In the future, determining the level of sociopsychological climate, we use the proposed formula:

$\mathrm{C}=\mathrm{A}-\mathrm{B}$, where

$\mathrm{C}$ - psychological climate

A - the total score of the marks on the left side of the form, responsible for the positive psychological climate.

B - the total score of the marks on the right side of the form, which correlates with the adverse social and psychological climate in the class.

If " $\mathrm{C}$ " is equal to zero or will be negative, then the climate in the classroom can be considered negative and unfavorable. If the value of " $\mathrm{C}$ " is greater than 0 , then the psychological climate of the class will be favorable. The favorable sociopsychological climate can be divided into three levels. Low from 0 to 2 points; the average - from 3 to 10 points and high - from 11 and more.

A sample. In our study, 15 school groups of high school (461 students) studied in two Poltava gymnasium- schools. The age was from 11 to 13 years (grades 5-7). There were 5 student groups, who studied in the fifth grade (161 students); 5 students who studied in the sixth form (146 pupils); and 5 from the students' groups who studied in the seventh grade (154 students). In total, the experiment involved 461, of which 239 boys and 222 girls. The classes are named in letters of the Latin alphabet, starting with "A" and ending with "O". We provide data for each class for comparison 
purposes. Finally, we summarize and compare all the results obtained.

Research results. Let's turn to a detailed review of the indicators of the psychological climate of the 5 classes. Among 161 students - 91 girls and 70 boys (Table 1).

Table 1. Average values of psychological climate among 5th grade students $(\mathrm{N}=161)$

\begin{tabular}{|c|c|c|c|c|c|}
\hline Class & $\begin{array}{c}\text { Number } \\
\text { of pupils }\end{array}$ & $\begin{array}{c}\text { Indicator } \\
\text { "A" }\end{array}$ & $\begin{array}{c}\text { Indicator } \\
\text { "B" }\end{array}$ & $\begin{array}{c}\text { Indicator } \\
\text { "C" }\end{array}$ & $\begin{array}{c}\text { Level of psycho- } \\
\text { logical climate }\end{array}$ \\
\hline «A» & 24 & 8,3 & 7,4 & 0,9 & Low \\
\hline$\ll \boldsymbol{B} »$ & 33 & 9,1 & 8,2 & 0,9 & Low \\
\hline «C» & 41 & 15,7 & 5,8 & 9,9 & Average \\
\hline «D» & 32 & 13,6 & 5,8 & 7,9 & Average \\
\hline «E» & 31 & 8,2 & 8,4 & $-0,6$ & Low \\
\hline
\end{tabular}

Studying the "A" class, which comprises 24 students, among which 14 boys and 10 girls, get such an average. $\mathrm{C}=$ 8.3-7.4 $=0.9$. This assessment of the psychological climate is an indicator of the low level of socio-psychological climate of the student group. Accordingly, we can testify about such properties of the class as conflict, the existence of groups that interact with each other, indifference to each other, intolerance to public opinion, the importance of personal interests beyond the interests of the group.

In "B" class there are 33 students - 18 boys and 15 girls. The level of socio-psychological climate is low: $\mathrm{C}=9,1-8,2$ $=0,9$. This indicator is low, and therefore the group is dominated by depressed mood, conflict, perhaps a grouping that conflicts with one another, indifference to each other, each considers its opinion to be the only correct one; in difficult situations, most likely, the quarrels and mutual accusations prevail.

Next, we will analyze the "C" class, which teaches 41 students, of which 25 boys and 16 girls. The level of psychological climate, calculated by the formula $C=15,7-5,8=9,9$. This result correlates with the average level of psychological climate in the group. This indicates a benevolent relationship in the group, the absence of sharp conflict situations, but insufficient emotional unity and complicity of all members of the group.

In the "D" class, which has 32 students, among them 19 boys and 13 girls, the following indicators of the psychological climate are obtained. $\mathrm{C}=13.6-5.8=7.9$. This assessment corresponds to the average level of socio-psychological climate, which involves the general affinity of all members of the group, joint leisure, goodwill in relationships, but focusing more on their own thoughts or on the opinions of microgroups than on the whole team as a single body.

Next in the table there is the result of " $\mathbf{E}$ " class, which involves 31 students - 15 boys and 16 girls. Sociopsychological climate of the group $\mathrm{C}=8,2-8,8=-0,6$. This indicator is low and indicates the low climate, the unfavorable psychological conditions in the team; the participants show indifference to their classmates, conflicts in their relationships occur rather often, the group is rather passive and inert.

Let's turn to the review of the results of the students who are studying in the sixth form. These are 5 academic groups 146 students -71 boys and 75 girls (table 2 ).

In the "F" class, this involves 30 students, among them 14 boys and 16 girls. Socio-psychological climate $C=9,8$ $7,8=2$. This indicator is rather low and close to 0 , so we can talk about the low level of socio-psychological climate of the student group. Accordingly, the group has properties such as: inertia, passivity in relationships, quarrels, the existence of groupings, conflicts in relationships, lack of a common strategy, everyone acting by his own mind, without listening to others, there is a disdainful attitude to the "unacceptable".

Table 2. Average values of the level of psychological climate among pupils of 6th grade $(\mathrm{N}=146)$

\begin{tabular}{|c|c|c|c|c|c|}
\hline Class & $\begin{array}{c}\text { Number } \\
\text { of pupils }\end{array}$ & $\begin{array}{c}\text { Indicator } \\
\text { "A" }\end{array}$ & $\begin{array}{c}\text { Indicator } \\
\text { "B" }\end{array}$ & $\begin{array}{c}\text { Indicator } \\
\text { "C" }\end{array}$ & $\begin{array}{c}\text { Level of psycho- } \\
\text { logical climate }\end{array}$ \\
\hline$\langle\boldsymbol{F} »$ & 30 & 9,8 & 7,8 & 2 & Low \\
\hline$\langle\boldsymbol{G} »$ & 29 & 9,8 & 9,4 & 0,4 & Low \\
\hline$\langle\boldsymbol{H} »$ & 30 & 17,6 & 4,4 & 13,2 & High \\
\hline$\langle\boldsymbol{I} »$ & 31 & 18,3 & 5,7 & 12,8 & High \\
\hline$\langle\boldsymbol{J} »$ & 26 & 16,9 & 5,3 & 11,6 & High \\
\hline
\end{tabular}

In "G" class there are 29 students, among them 13 boys and 16 girls. The indicators of socio-psychological climate are as following $\mathrm{C}=9,8-9,4=0,4$, which corresponds to low levels. So, we can assume that conflict, inertia, passivity of the group, a success or failure can cause indifference among other participants. It is possible to divide the group into microgroups that conflict with each other.

After conducting the research in the "H" class, where we had 30 students, of which 15 boys and 15 girls, the following average indicators of the psychological climate were received. $\mathrm{C}=17.6-4.4=13.2$. This assessment corresponds to a high level of socio-psychological climate of the team. So, we can state such properties of the group as mutual sympathies, joint rest, complicity of all members of the group, emotional unity and the desire to work collectively.

In the class "I" there are 31 students - 15 boys and 16 girls. The level of psychological climate is high, because $\mathrm{C}=$ $18.3-5.7=12.8$. So, we can talk about energy, activity of the group, the presence of the "we", the frank complicity of each in the group, emotional unity and the desire to work collectively in education and in leisure.

The following is the result of the study " $\mathbf{J}$ " class, where 26 students are studying, including 14 boys and 12 girls. Socio-psychological climate of the group $C=16,9-5,3=$ 11,6. This indicator indicates a high level of psychological climate, which manifests itself in the benevolence in relationships, the existence of a common goal, mutual respect, a sense of emotional unity and participation of participants in the student class. Among the students who studied in the seventh grade, there were 154 students, including 77 boys and 77 girls, the following results were found (Table 3):

\begin{tabular}{|l|c|c|c|c|c|}
\hline Class & $\begin{array}{c}\text { Number } \\
\text { of pupils }\end{array}$ & $\begin{array}{l}\text { Indicator } \\
\text { "A" }\end{array}$ & $\begin{array}{c}\text { Indicator } \\
\text { "B" }\end{array}$ & $\begin{array}{c}\text { Indicator } \\
\text { "C" }\end{array}$ & $\begin{array}{c}\text { Level of psycho- } \\
\text { logical climate }\end{array}$ \\
\hline$\ll \boldsymbol{K} »$ & 36 & 16,5 & 5,7 & 10,8 & Average \\
\hline$\ll \boldsymbol{L} »$ & 31 & 16,5 & 14,8 & 11,7 & High \\
\hline$\ll \boldsymbol{M} »$ & 32 & 13,8 & 6,4 & 7,3 & Average \\
\hline$\ll \boldsymbol{N} »$ & 27 & 16,1 & 5,8 & 10,3 & Average \\
\hline$\ll \boldsymbol{O} »$ & 28 & 16,0 & 5,4 & 10,6 & Average \\
\hline
\end{tabular}

Table 3. Average values of psychological climate among 7th grade students $(\mathrm{N}=154)$

As a result of the study of the "K" class, with 36 students, including 20 boys and 16 girls, we confirm that they have an average assessment of the psychological climate using the formula $\mathrm{C}=\mathrm{A}-\mathrm{B}$, respectively $-\mathrm{C}=16.5-5.7=10,8$ This assessment correlates with the average level of psychological climate, which ensures goodwill in relationships, group 
activities outside the teaching, respect for each other's thoughts, activity, energy of the class participants.

In the class "L", which consists of 31 students - 13 boys and 18 girls got the following average indicator of the psychological climate: $\mathrm{C}=16,5-4,8=11,7$. This assessment corresponds to a high level of socio-psychological climate, which involves a shared sense of pride for the group, mutual respect among the group members, the enthusiasm for common deeds and the participation of the group members.

Exploring the class "M", in which 32 students - 15 boys and 17 girls, the following indicators were obtained: $\mathrm{C}=$ 13.8-6.4 = 7.3. This assessment corresponds to the average level of socio-psychological climate, and therefore the group has a good atmosphere for studying, students are friendly, there are mutual sympathies, they like to spend time together when performing both educational tasks and extra-curricular activities.

In the class "N", where 27 students are studying, among which 14 boys and 13 girls showed the following results: C $=16,1-5,8=10,3$. This indicator correlates with the average level of the socio-psychological climate of the team, because the students are positively related to each other, have mutual sympathies, understanding, they like to spend time together, respectfully refer to the views of others.

After examining the socio-psychological climate in the "O" class, which consists of 28 students - 15 boys and 13 girls, the following was found: $\mathrm{C}=16,0-5,4=10,6$. This estimation correlates with the average level of sociopsychological climate. So we can talk about the group's properties such as benevolence to one another, holding together extra-curricular time, respect for each other's thoughts, mutual sympathy, vigor and activity.

Discussion of results. Comparing the results of the study of socio-psychological climate of 15 classes, the data can be presented in Table 4.

So, as can be seen from Figure 2, 27\% of pupils' groups have a high level of socio-psychological climate, which implies such group's qualities as emotional unity, mutual respect, enjoyment of joint activity, friendly relations both in educational activities and in leisure, having a sense of pride in their group. $40 \%$ of pupils' groups have an average psychological climate, which also includes benevolence in relationships, mutual sympathies, shared leisure, fair treatment for all, and the enthusiasm of common affairs. The remaining $33 \%$ of the students' groups demonstrated a low level of socio-psychological climate, which provides the least favorable conditions for learning and development. Indeed, in such groups, there are likely to be certain groups that are in conflict, the groups are inert, indifferent to each other, do not listen to the common opinion, act separpately, each one considerstheir opinion as the main and the only correct one, which may lead to controversy and misunderstanding.

Table 4. General values of the level of psychological climate among high school students

\begin{tabular}{|c|c|c|c|c|c|c|c|c|c|c|c|c|c|c|c|}
\hline & \multicolumn{5}{|c|}{$5^{\text {th }}$ grade } & \multicolumn{5}{|c|}{$6^{\text {th }}$ grades } & \multicolumn{5}{|c|}{$7^{\text {th }}$ grade } \\
\hline Class & A & B & $\mathbf{C}$ & D & $\mathbf{E}$ & $\mathbf{F}$ & G & $\mathbf{H}$ & I & $\mathbf{J}$ & $\mathbf{K}$ & $\mathbf{L}$ & $\mathbf{M}$ & $\mathbf{N}$ & O \\
\hline Level & 3 & בְּ & 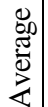 & 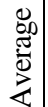 & $\begin{array}{l}3 \\
0 \\
3\end{array}$ & 3 & בְּ & $\begin{array}{l}.50 \\
.00 \\
07\end{array}$ & 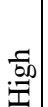 & $\begin{array}{l}\overrightarrow{50} \\
.00\end{array}$ & 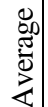 & $\underset{7}{50}$ & 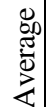 & 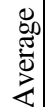 & 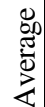 \\
\hline
\end{tabular}

Having grouped the received data on the levels of social and psychological climate, it was revealed that 4 classes have a high level of psychological climate, 6 classes - the average level and 5 classes - low. Accordingly, we can depict this relation on the next fig.1.

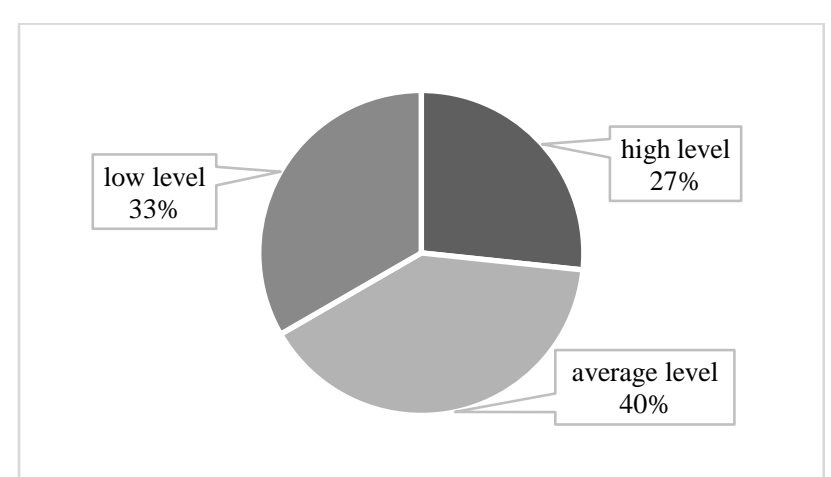

Figure 1. Socio-psychological climate of high school students' groups

Having performed a statistical analysis of the results, comparing the scores obtained by girls and boys with the UMann-Whitney criterion, there was no difference in the statistical significance $(U=26406.5 ; p=0.93)$. So, there are no differences in the assessment of the psychological climate among boys and girls.

Comparing the levels of psychological climate among 5, 6 and 7 classes, we calculate the average arithmetic indicators in these student groups (Table 5).

Table 5. Average values of the level of psychological climate among students $5,6,7$ classes

\begin{tabular}{|l|c|c|c|}
\hline Classes & $\mathbf{5}^{\text {th }}$ grades & $\mathbf{6}^{\text {th }}$ grades & $\mathbf{7}^{\text {th }}$ grade \\
\hline Number of pupils & 161 & 146 & 154 \\
\hline Average "C" & 4,3 & 8 & 10,1 \\
\hline
\end{tabular}

Graphically, the results can be presented in the form of the following histogram (Fig. 2):

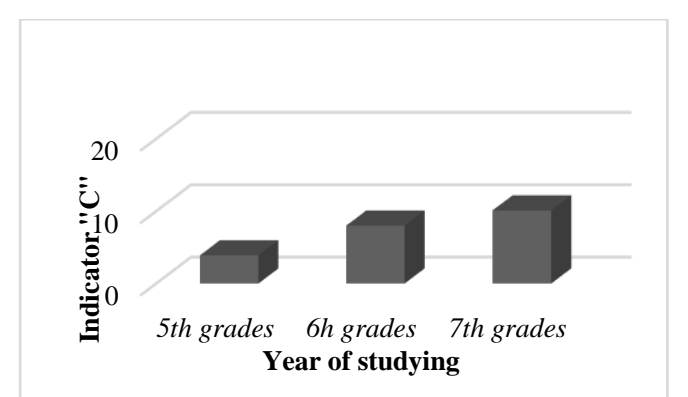

Figure 2. Average values of the level of psychological climate among students of 5th, 6th, 7th grades

To determine the statistical significance of the differences between pupils of 5, 6, and 7 classes, an analysis was carried out on non-parametric U-criterion Mann-Whitney. Thus, the results of pupils of 5th and 6th grades, 6th and 7th grades and 5 th and 7 th grades were compared in pairs. By comparing the results of 5th and 6th classes, the U-criterion $=8155(\mathrm{p}=$ 0.000 ), indicating a high level of statistical significance of differences in results. Comparing the indices of 6 th and 7 th grades, we have $U=9412(\mathrm{p}=0.014)$, which also indicates a high statistical significance. And, between 5th and 7th grades, $\mathrm{U}=5465.5(\mathrm{p}=0.000)$, respectively, also high statistical significance of differences. The results were scanned using the SPSS program. 
Consequently, as a result of our study, it was found that the level of psychological climate among the students who are studying in the 5th grade is lower than in the 6th and 7 th grade students. The results of the study are statistically significant. It should be noted that the study was cut-off, not longitudinal, ie, the students under study were tested once only, but not for a certain period. The level of psychological climate and not its dynamics was studied. The results obtained can be related to a number of objective and subjective factors. One of the reasons may be the age characteristics of the students, because at that time they enter into adolescence period, which involves close interpersonal communication and relationships with peers. We can also talk about the external influence on the student group of students, especially class leaders. It should be noted that the influence of the teacher plays an important role in forming a good psychological climate of the class and the comfort of all members of the group.

Conclusions. Thus, the socio-psychological climate of the student community is extremely important both for the successful functioning of the team and for the harmonious development of students' personalities. High school students who are adolescents are experiencing a complex and controversial period of life, full of mental changes and development. It is at this age that the leading place is the environment - in the form of a team of classmates and significant adults - teachers. That is why it is expedient to study the psychological climate of student groups. Among the 15 students who were studied, $67 \%$ have a favorable socio-psychological climate, and only $33 \%$ have less favorable, inclined to the unfavorable one. Very low results (less than 0), which would indicate the adverse psychological climate was not revealed. In general the obtained results show a rather good picture. Most of the students surveyed are satisfied with the psychological climate in their team, which promotes both the development of the collective as a whole and the individual personal development of students as well. Comparing the results among the 5th, 6th, and 7th grade students, a high level of statistical significance of differences was revealed, in particular, the level of psychological climate in students of the 5th grade is significantly lower than in the 6th grade students, and the psychological climate of the 6th grade is lower than in the 7 th grade students. Due to the fact that the results of the study of students studying in the 5th 6th and 7th grades are significantly different, it will be interesting to continue the study again, with the aim of continuous and and long term observation of the dynamics in changes of the psychological climate during the studies in high schools.
1. Паригін Б. Д. Соціальна психологія //Спб.: ГУП. - 1999.

2. Пушкар 3., Войтович Г. Соціально-психологічний клімат в колективі та чинники, що впливають на його формування. 2013.

3. Седих К. В. Делінквентний підліток: навч. посібн //К.: Видавничий Дім «Слово. -2015.

4. Седих К. В. Психологія взаємодії систем:“сім'я і освітні інституції'[монографія]/К. Седих //Полтава: Довкіл ля. 2008.

5. Freiberg H. J. School climate: Measuring, improving and sustaining healthy learning environments. - Routledge, 2005..

6. Joe H. K., Hiver P., Al-Hoorie A. H. Classroom social climate, self-determined motivation, willingness to communicate, and

\section{REFERENCES}

achievement: A study of structural relationships in instructed second language settings //Learning and Individual Differences. - 2017. - T. 53. - C. 133-144.

7. Parker C. P. et al. Relationships between psychological climate perceptions and work outcomes: a meta-analytic review //Journal of Organizational Behavior: The International Journal of Industrial, Occupational and Organizational Psychology and Behavior. - 2003. - T. 24. - №. 4. - C. 389-416.

8. Sriklaub K., Wongwanich S., Wiratchai N. Development of the classroom climate measurement model //Procedia-Social and Behavioral Sciences. - 2015. - T. 171. - C. 1353-1359.
1. Paryhin B. D. Sotsialna psykholohiia //Spb.: HUP. - 1999.

2. Pushkar Z., Voitovych H. Sotsialno-psykholohichnyi klimat v kolektyvi ta chynnyky, shcho vplyvaiut na yoho formuvannia. 2013.

3. Sedykh K. V. Delinkventnyi pidlitok: navch. posibn //K.: Vydavnychyi Dim «Slovo. - 2015.

4. Sedykh K. V. Psykholohiia vzaiemodii system:"simia i osvitni instytutsii”'[monohrafiia]/K. Sedykh //Poltava: Dovkil lia. - 2008.

5. Freiberg H. J. School climate: Measuring, improving and sustaining healthy learning environments. - Routledge, 2005.

6. Joe H. K., Hiver P., Al-Hoorie A. H. Classroom social climate, self-determined motivation, willingness to communicate, and

\section{REFERENCES}

achievement: A study of structural relationships in instructed second language settings //Learning and Individual Differences. - 2017. - T. 53. - C. 133-144.

7. Parker C. P. et al. Relationships between psychological climate perceptions and work outcomes: a meta-analytic review //Journal of Organizational Behavior: The International Journal of Industrial, Occupational and Organizational Psychology and Behavior. - 2003. - T. 24. - №. 4. - C. 389-416.

8. Sriklaub K., Wongwanich S., Wiratchai N. Development of the classroom climate measurement model //Procedia-Social and Behavioral Sciences. - 2015. - T. 171. - C. 1353-1359. 